\title{
Size fractionation of phosphorus (dissolved, colloidal and particulate) in two tributaries to Lake Lugano
}

\author{
Sabine Hilger ${ }^{1}$, Laura Sigg ${ }^{1, *}$ and Alberto Barbieri ${ }^{2}$ \\ ${ }^{1}$ Swiss Federal Institute for Environmental Science and Technology, EAWAG, \\ CH-8600 Dübendorf, Switzerland \\ ${ }^{2}$ Laboratorio Studi Ambientali, Sezione Protezione Aria e Acqua, Dipartimento del Territorio, \\ CH-6500 Bellinzona, Cantone Ticino, Switzerland
}

Key words: Colloids, particles, cross-flow filtration, phosphorus, bioavailability

\begin{abstract}
An in-situ fractionation mainly consisting of continuous flow centrifugation and cross-flow-ultrafiltration was used to separate a particulate (particle diameter $>1 \mu \mathrm{m}$ ), a colloidal (particle diameter $<1 \mu \mathrm{m}$ and molecular weight $>10 \mathrm{kD}$ ) and a dissolved fraction (molecular weight $<10 \mathrm{kD}$ ) of total phosphorus in river water. A similar fractionation pattern is observed in function of discharge in two tributaries to Lake Lugano, the rivers Cassarate and Vedeggio. In Cassarate river $31 \%$ of the total $\mathrm{P}$ is particulate, $10 \%$ colloidal and $59 \%$ dissolved at low discharge, whereas at high discharge $73 \%$ is particulate, $10 \%$ colloidal and $17 \%$ dissolved. $19 \%$ of the total P is particulate, $12 \%$ colloidal and $69 \%$ dissolved at low discharge in Vedeggio river, and at high discharge $19 \%$ of the total $\mathrm{P}$ is dissolved, $8 \%$ colloidal and $73 \%$ particulate. Release of ortho-phosphate (o-P) from Cassarate and Vedeggio colloids was observed at $\mathrm{pH} 10$, and by the enzyme alkaline phosphatase in laboratory experiments. Calculations of a model based annual P-load into Lake Lugano showed an average total P-distribution with $60 \%$ particulate P, $10 \%$ colloidal P and $30 \%$ dissolved P in Cassarate and Vedeggio river for 1996 and 1997.
\end{abstract}

\section{Introduction}

Phosphorus concentrations in rivers and lakes had increased until the late 70 s in Switzerland due to industrialization, population growth and intensive agricultural development. Increased P-inputs lead to eutrophication of many lakes (BUWAL, 1994; Gächter and Stadelmann, 1993; Vollenweider, 1968). The physico-chemical evolution of nutrients, phyto- and zooplankton in Lake Lugano has been investigated (Barbieri and Mosello, 1992; Imboden, 1992; Lachavanne et al., 1992; Lami et al., 1992; Lazzaretti et al., 1992; LSA, 1998; Müller and Meng, 1992, Polli and Simona, 1992; Zamboni et al., 1992) The water quality could be improved by the P-pro-

\footnotetext{
* Corresponding author.
} 
hibition in detergents since 1985 and the development of sewage treatment plants (Baccini, 1985; Gächter and Wüest, 1992; Siegrist and Boller, 1996; Wehrli and Wüest, 1996). However, the P-inputs into Lake Lugano are still too high, which means that the trophic status does not improve (Barbieri and Mosello, 1992; LSA, 1998). Although some authors have assumed that colloidal $\mathrm{P}$ was an important transient within the P-cycle (Rigler, 1964; Jackson and Schindler, 1975; Lean, 1973; Paerl and Lean, 1976), no detailed study about colloidal P in freshwater exists. In this study the P-input from two main tributaries into Lake Lugano is characterized in detail with emphasis on the role of colloids and particles.

Colloids are small particles in the size range of $1 \mathrm{~nm}$ to $1 \mu \mathrm{m}$ and are important reactants in the fate of trace metals, pollutants and nutrients (Buffle and van Leeuwen, 1992; Everett, 1988). Due to their dynamic behaviour and their small amount of mass, sampling of colloids from lakes and rivers is very challenging, and various methods have been used for fractionation (e.g., Hoffmann et al., 1981; Buffle et al. 1995a; Buesseler et al., 1996). The most widely used technique for sampling colloids is cross-flow filtration, with a prefiltration or centrifugation step to remove larger particles (Buesseler et al., 1996; Gustafsson and Gschwend, 1997; Lead et al., 1997). We chose here a combination of continuous centrifugation and cross-flow ultrafiltration for sampling and fractionation of river water. The main questions in our study were: How does the P-distribution among various size fractions vary with discharge? How are the P-inputs distributed among dissolved, colloidal and particulate fractions? Which mechanisms lead to an ortho-P-release from colloidal P?

\section{Materials and methods}

\section{Sampling site}

Lake Lugano is an alpine lake in the southern part of Switzerland near Italy. Due to its morphology it is divided into a northern $\left(270 \mathrm{~km}^{2}\right)$ and a southern basin $\left(290 \mathrm{~km}^{2}\right)$. Samples were collected from two tributaries, the river Cassarate for the Northern basin and the Vedeggio for the Southern basin (Fig. 1). Both sampling sites were close to the mouth and located at water-level stations, where the discharge has been measured continuously by the authorities of Cantone Ticino (LSA).

The mean annual discharge comprises $3.87 \mathrm{~m}^{3} \mathrm{~s}^{-1}$ (1979-1993) for the river Vedeggio and $2.57 \mathrm{~m}^{3} \mathrm{~s}^{-1}$ (1963-1993) for the river Cassarate (LSA, 1996). Typical for both river regimes are two high flood events, one occurring in the late spring (May/June) and the other later in autumn (Oct/Nov). The discharge maxima are about 20-40 times higher than the mean annual discharge in Vedeggio and Cassarate.

Due to the crystalline background both rivers have at average discharge low alkalinity (Cassarate 1.0-1.4 mM, Vedeggio 0.8-1.4 mM), low Ca-concentrations (Cassarate $0.39-0.65 \mathrm{mM}$ and Vedeggio $0.48-0.70 \mathrm{mM}$ ) and low ionic strength (Cassarate $3 \times 10^{-3} \mathrm{M}$; Vedeggio $4 \times 10^{-3} \mathrm{M}$ ). $\mathrm{pH}$ is $7.4-7.9$ in Cassarate river and 7.0-7.6 in Vedeggio river. Conductivity varies with discharge, under low discharge 


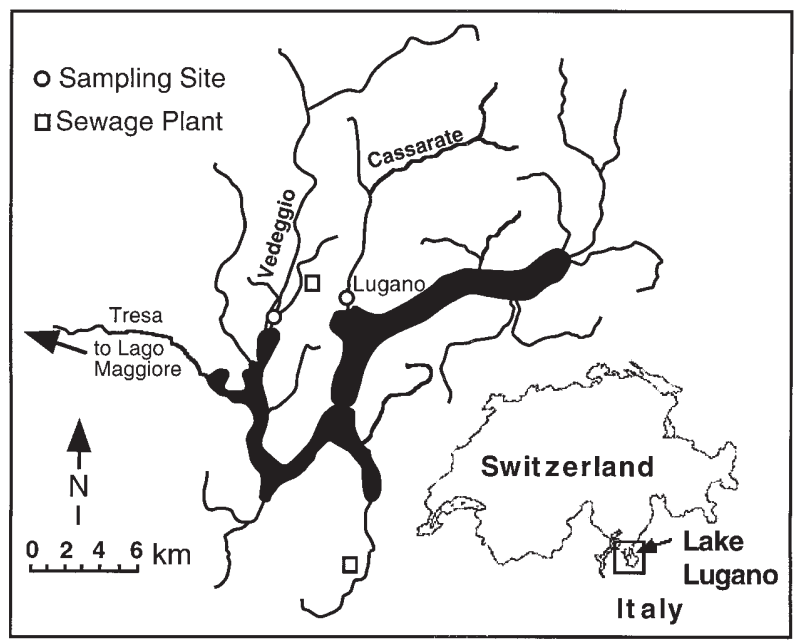

Figure 1. Map of Lake Lugano (Adapted from Karagounis, 1992)

it comprises between $200-400 \mu \mathrm{S} \mathrm{cm} \mathrm{cm}^{-1}$ in Cassarate and $240-500 \mu \mathrm{S} \mathrm{cm} \mathrm{cm}^{-1}$ in Vedeggio and under high discharge $80-100 \mu \mathrm{S} \mathrm{cm} \mathrm{cm}^{-1}$ and $50-100 \mu \mathrm{S} \mathrm{cm} \mathrm{cm}^{-1}$ respectively.

\section{In-situ fractionation}

A separation of river water into three operationally defined size classes, a particulate, a colloidal and a dissolved fraction was performed with an in-situ fractionation device consisting of a continuous-flow centrifugation and a cross-flow ultrafiltration. The particulate fraction is defined as particles, which have a diameter $>1 \mu \mathrm{m}$. Colloids are defined as submicron particles or macromolecules which have a diameter $<1 \mu \mathrm{m}$ and a molecular weight $>10 \mathrm{kD}$. The dissolved fraction (ultrafiltrate) is defined as the size range of molecules and ions which pass a $10 \mathrm{kD}$ membrane. The distinction between the colloidal and the dissolved fraction is operationally defined according to the cross-flow ultrafiltration device used and to the theoretical cut-off of $10 \mathrm{kD}$.

Sampling was performed at least at $1 \mathrm{~m}$ distance from the bank at a water level approximately $25 \%$ of the depth below the surface. The river water was sampled continuously with a peristaltic pump and directly centrifuged. The centrifuge (LE 402-18091, CEPA) was operated at $25000 \mathrm{rpm}$ with a flow rate of $1.21 \mathrm{~min}^{-1}$. SEM pictures and particle size analysis of the outlet from the centrifuge (not shown) defined a cut-off range of about $1 \mu \mathrm{m}$ as a function of the morphology and density of the particles. Particles $>1 \mu \mathrm{m}$ were collected on a teflon sheet inside the centrifuge. The inlet port was made of teflon, all tubes consisted of either silicone or teflon, the retentate vessel and connecting pieces consisted of polypropylene (PPE). The outlet of the centrifuge containing the colloids and the dissolved fraction was 
directly filtered with a cross-flow ultrafiltration (Filtron and Watson Marlor $701 \mathrm{~S}$ ) equipped with two $10 \mathrm{kD}$ low protein binding modified polyethersulfone membranes (Omega, 5 SQ Feet Filtron). Concentration factors for the colloidal retentate ranged between 3 and 130 depending on the river discharge. The flow rate of the ultrafiltrate ranged between $0.6-0.91 \mathrm{~min}^{-1}$.

The size distribution in the colloidal and ultrafiltrate fraction was examined by dynamic light scattering (Schurtenberger and Newman, 1993). Smooth particle size distributions in the range $5-1000 \mathrm{~nm}$ were observed in the colloidal fraction, with calculated mean radii of about $200 \mathrm{~nm}$ (Hilger, 1998). No particles larger than $5 \mathrm{~nm}$ were detected in the ultrafiltrate.

The cross-flow ultrafiltration was cleaned with $0.05 \mathrm{M} \mathrm{NaOH}$ suprapure for $15 \mathrm{~min}$ prior to use and after each filtration. The membrane was stored in $0.05 \mathrm{M} \mathrm{NaOH}$ suprapure at $4{ }^{\circ} \mathrm{C}$ in the dark. After cleaning with $\mathrm{NaOH}$ the crossflow ultrafiltration was rinsed with nanopure water until neutral $\mathrm{pH}$ was reached (10-20 1). To minimize sorption losses on tubes and vessels, 101 centrifuged river water were also used to rinse the CFF prior to filtration. The in-situ fractionation was checked with nanopure water for blanks. All P-concentrations were below the detection limit of $0.1 \mu \mathrm{M}$. DOC-concentrations were $<25 \mu \mathrm{M}$ after the centrifugation step, $25-33 \mu \mathrm{M}$ in the ultrafiltrate and $75 \mu \mathrm{M}$ in the retentate.

A smaller CFF (Mini-Ultrasette, Filtron, screen channel, Omega membrane, cut-off $10 \mathrm{kD}$ ) was used for parallel sampling from both rivers during high flood events and also for laboratory experiments, where three Mini-Ultrasettes were run in parallel with a peristaltic pump (504U SKAN AG- Smith \& Nephew Watson Marlow; Masterflex model 7554-50; Ismatec SA Typ VP 46-0084). The pump speed was adjusted to an ultrafiltrate flow rate of $300 \mathrm{ml} \mathrm{min}^{-1}$. Blanks run with the MiniUltrasette showed no P- and DOC-contamination both in the retentate and in the ultrafiltrate; P-concentrations were $<0.1 \mu \mathrm{M}$ and DOC-concentrations were $<25 \mu \mathrm{M}$ respectively. The Mini-Ultrasettes were cleaned in the same way as the $\mathrm{CFF}$ and stored after the $\mathrm{NaOH}$-cleaning at $4{ }^{\circ} \mathrm{C}$.

Our OC-blanks are in the same order of magnitude as those reported in other studies, e.g. 25 to $33 \mu \mathrm{M} \mathrm{C}$ (Eyrolle et al., 1996), and $<10 \mu \mathrm{M}$ to a maximum value of $200 \mu \mathrm{M}$ in an intercomparison study by Buesseler et al. (1996), in which 14 crossflow filtration systems were tested, but not all systems had been optimized with respect to C-blanks. The P-blanks for the in-situ fractionation were all below the detection limit of $0.1 \mu \mathrm{M}$. A filtration test with $\mathrm{KH}_{2} \mathrm{PO}_{4}$-standard solution showed a deviation at the most of $19 \%$ which is comparable to the mass balance results of the in-situ fractionation with river water; no significant accumulation of o-P in the retentate was observed.

\section{$P$ and $O C$-mass balances}

Mass balances for the in-situ fractionation were calculated as the sum of the concentrations in the particulate, colloidal and dissolved fraction, which were compared with the mean value of two untreated river water samples taken at the beginning and the end of each sampling campaign. 


$$
\begin{aligned}
& \mathrm{P}_{\text {tot }}=\mathrm{P}_{\text {part }}+\mathrm{P}_{\text {coll }}+\mathrm{P}_{\text {diss }} \\
& \mathrm{P}_{\text {part }}=\mathrm{SS} \times \mathrm{PP},
\end{aligned}
$$

where

$\mathrm{P}_{\text {tot }}=$ total $\mathrm{P}$ concentration $[\mu \mathrm{M}]$

$\mathrm{P}_{\mathrm{part}}=$ particulate $\mathrm{P}$ concentration $[\mu \mathrm{M}]$

$\mathrm{P}_{\text {coll }}=$ colloidal $\mathrm{P}$ concentration $[\mu \mathrm{M}]$

$\mathrm{P}_{\text {diss }}=$ dissolved $\mathrm{P}$ concentration $[\mu \mathrm{M}]$

$\mathrm{SS}=$ suspended solid content $\left[\mathrm{g} \mathrm{l}^{-1}\right]$

$\mathrm{PP}=\mathrm{P}$ content in particles $\left[\mu \mathrm{mol} \mathrm{g}^{-1}\right]$

$\mathrm{P}_{\text {coll }}$ is calculated as:

$$
\mathrm{P}_{\text {coll }}=\left(\mathrm{P}_{\text {tot ret }}-\mathrm{P}_{\text {tot diss }}\right) / \mathrm{cf}
$$

where:

$\mathrm{P}_{\text {tot ret }}=$ total $\mathrm{P}$ concentration in retentate $[\mu \mathrm{M}]$

$\mathrm{P}_{\text {tot diss }}=$ total $\mathrm{P}$ concentration in ultrafiltrate $[\mu \mathrm{M}]$

$\mathrm{cf}=$ concentration factor, calculated from the total volume filtered divided by the final retentate volume.

\section{Calculation of the P-distribution in the annual load}

The mean results of the fractionation under low and high discharge were combined with the data of a model from LSA. This model calculates monthly loads based on a discharge-concentration relation. Input data are total and dissolved $(0.45-\mu \mathrm{m}$ filtered) P-measurements based on weekly and fortnightly sampling (LSA, 1998). Months with a P-load $<8 \%$ of the annual P-load were summarized and multiplied with the proportionate P-fractionation under low discharge. Months with a P-load $>8 \%$ of the annual P-load were multiplied with the proportionate P-fractionation under high discharge.

\section{Release of o-P from the colloidal fraction}

The release of o-P from colloids, which is supposed to be directly utilisable for algae and bacteria, was examined in laboratory experiments. The influence of increased $\mathrm{pH}$ up to 10.2 in a colloidal river suspension was examined over time. Higher $\mathrm{pH}$ values $(\mathrm{pH} 10)$ than those encountered in lakes were used in some of the experiments to better evaluate the effects of alkaline conditions.

In three replicates of $250 \mathrm{ml}$ colloidal suspension $\mathrm{pH}$ was stepwise adjusted to 8.3, 9.0 and 10.0-10.2 with $0.1 \mathrm{M} \mathrm{NaOH}$ suprapure under nitrogen gas atmosphere. After $15 \mathrm{~min} 5 \mathrm{ml}$ aliquots were filtered with a $0.2 \mu \mathrm{m}$ syringe filter (Sartorius Minisart-plus $17823 \mathrm{~K}$ ) into two $2 \mathrm{ml}$ vials for direct o-P-measurements with an Autoanalyzer. Blanks were done with nanopure water to test the reagents and the o-P-concentration was followed over time in colloidal suspensions at the original $\mathrm{pH}$ of 7.8. 
In another set of experiments, the effect of an enzyme, alkaline phosphatase derived from Escherichia coli (SIGMA P 4252, Type III), was investigated to release o-P from colloids. These experiments were run at 20 and $30^{\circ} \mathrm{C}$. A temperature of $30^{\circ} \mathrm{C}$ is close to the optimum temperature of this enzyme, whereas $20^{\circ} \mathrm{C}$ corresponds to the summer temperatures $\left(18-22^{\circ} \mathrm{C}\right)$ in the epilimnion of L. Lugano. Cross-flow ultrafiltration of the colloidal suspensions was performed using three Mini-Ultrasettes, with $10 \mathrm{kD}$ membranes, through which the alkaline phosphatase with a molecular weight of about 160000 (Bretaudiere and Spillman, 1984) could not pass. After addition of the alkaline phosphatase prepared in a $0.1 \mathrm{M}$ Tris- $\mathrm{HCl} /$ $0.1 \mathrm{M} \mathrm{NaCl}$-buffer solution to $150-250 \mathrm{ml}$ colloidal suspension in Erlenmeyer flasks the o-P-concentration was followed over time in the ultrafiltrate. Enzyme preparation was done under sterile conditions, and enzymatic activity was tested with a standard method (E.C. 3.1.3.1). All glassware was presoaked in $0.01 \mathrm{M} \mathrm{HNO}_{3}$ suprapure for $24 \mathrm{~h}$ prior to the experiments. As a control the o-P concentration in the ultrafiltrate was followed over time after adding the same amount of tris-buffersolution as in the experiments without alkaline phosphatase.

\section{Analytical methods}

All samples were transported and stored at $4^{\circ} \mathrm{C}$ in the dark and analyzed within $48 \mathrm{~h}$ after sampling. Particles were lyophilized and digested in a microwave oven (Microwave Laboratory Systems, mls 1200 mega) with nitric acid (suprapure) and hydrogen peroxide prior to element analysis. Aliquots from colloidal retentate suspension and ultrafiltrate were digested in the same way prior to metal analyses. The total particulate phosphorus was analysed with a spectrophotometer using the molybdenum blue method (APHA et al., 1995). The standard reference material 2704 Buffalo River Sediment (U.S. Department of Commerce National Institute of Standards and Technology Gaithersburg, MD 20899) was used as reference material for $\mathrm{P}$ and metal analyses. Aliquots from untreated river water, colloidal retentate and ultrafiltrate were digested with the $\mathrm{K}_{2} \mathrm{~S}_{2} \mathrm{O}_{8}$-method and measured as ortho-phosphate (o-P) with the ascorbate-acid method with an autoanalyser (Technicon Autoanalyzer II and Technicon SC Colorimeter) at a wavelength of $880 \mathrm{~nm}$ (APHA et al., 1995). Sampling devices for metal analyses were pre-soaked with $0.01 \mathrm{M} \mathrm{HNO}_{3}$. Ca, $\mathrm{Mg}, \mathrm{Fe}$ and $\mathrm{Mn}$ were measured after digestion with $\mathrm{HNO}_{3} / \mathrm{H}_{2} \mathrm{O}_{2}$ in a microwave with ICP-OES (Spectro Analytical instruments). Samples for total and dissolved organic carbon were directly acidified with $\mathrm{HCl}(\mathrm{pH} 1)$ in the field. Total organic carbon (TOC) was homogenized prior to analysis. TOC, colloidal organic carbon (COC) and dissolved organic carbon (DOC) were measured with a carbon analyzer (Shimadzu Total Organic Carbon Analyzer TOC 500, ASI 502). The standard deviation for TOC-analyses ranged from 5 to $11 \%$ with two replicates and 5 injections each. Particulate organic carbon (POC) was determined with a CHNS element analyzer in lyophilized particles (Vario EL; Elementare Analysensysteme GmbH Hanau, Germany). The suspended solid (SS) content of river water samples was determined gravimetrically. Prewashed and weighted Sartorius cellulose nitrate filters $(11306-50 \mathrm{~N})$ with a pore size of $0.45 \mu \mathrm{m}$ were used for the vacuum filtration of the suspended solids. Standard deviation varied between 
$0-25 \%(\mathrm{n}=2)$, for SS-content $>5 \mathrm{mg} \mathrm{l}^{-1}$, the standard deviation is $<5 \%$. Conductivity and temperature were directly measured in the field with a Teso 240 conductivity meter. A WTW pH 323-A/set 1 pH-meter was used for direct $\mathrm{pH}$-measurements. Alkalinity was determined with a Metrohm 670 automatic titrator in filtered samples.

\section{Results}

\section{In-situ fractionation}

The P- and OC-distribution over the size fractions show a clear dependence from the discharge in both rivers (Tables 1 and 2). Under low discharge the mean total $\mathrm{P}$-concentration is $1.2 \mu \mathrm{M}$ in Cassarate river $(\mathrm{n}=10) .31 \%$ of the total $\mathrm{P}$ is particulate, $10 \%$ colloidal and 59\% dissolved. Under high discharge, the mean total Pconcentration is $5.4 \mu \mathrm{M}$, the total $\mathrm{P}$ is dominated by the particulate fraction, which comprises $73 \%$ of total $\mathrm{P}, 10 \%$ is colloidal $\mathrm{P}$ and $17 \%$ is dissolved $\mathrm{P}$ (for detailed information see Table 1). The Vedeggio river shows a similar fractionation pattern: Under low discharge, the total mean P-concentration is $1.5 \mu \mathrm{M}, 19 \%$ of the total $\mathrm{P}$ is particulate, $12 \%$ colloidal and $69 \%$ dissolved $(n=8)$. Under high discharge, the mean total P-concentration is $5.9 \mu \mathrm{M}(\mathrm{n}=6), 19 \%$ of the total $\mathrm{P}$ is dissolved, $8 \%$ is colloidal and $73 \%$ is particulate (for detailed information see Table 2).

The OC-concentrations in the three defined fractions show a similar behaviour in dependence from the discharge, where the particulate and dissolved fraction are strongly influenced by the discharge. Under low discharge conditions, the dissolved ultrafiltered organic carbon (UF-DOC) and colloidal organic carbon (COC) comprise between 80 and $95 \%$ of the TOC, with $1-17 \%$ being colloidal OC. Under higher discharge, the UF-DOC comprises between $19-54 \%$ of the TOC, the COC between $4-16 \%$ and the particulate organic carbon (POC) $41-79 \%$. Tables 3 and 4 show the OC-distribution over size fractions of Cassarate and Vedeggio river samples and the mass balances of the in-situ fractionation. In general, the sum of the POC, COC and UF-DOC from the in-situ fractionation comprise $116 \pm 13 \%$ of the TOC $(\mathrm{n}=10)$ compared with the measured TOC in an unfractionated Cassarate sample, taken as a reference value. Additionally the sum of the COC and UF-DOC was compared with measurements of DOC in a directly in the field $0.45-\mu \mathrm{m}$-filtered sample. The sum of ultrafiltered DOC and COC comprise $99 \pm 18 \%(n=8)$ of the DOC in the $0.45-\mu \mathrm{m}$-filtered Cassarate river sample. In Vedeggio river, the sum of UF-DOC, COC and POC comprises $114 \pm 12 \%(n=7)$ of the TOC of a unfractionated reference river sample. Some samples at high discharge (nr. 12-14, Table 4) show much higher discrepancies between the sum of the size fractions and the measured TOC, which are due to TOC losses by sedimentation in samples with high particle concentrations. The sum of ultrafiltered DOC and COC also shows a reasonable mass balance comprising $100 \pm 14 \%(n=9)$ of the DOC of a $0.45 \mu \mathrm{m}-$ filtered river sample. 


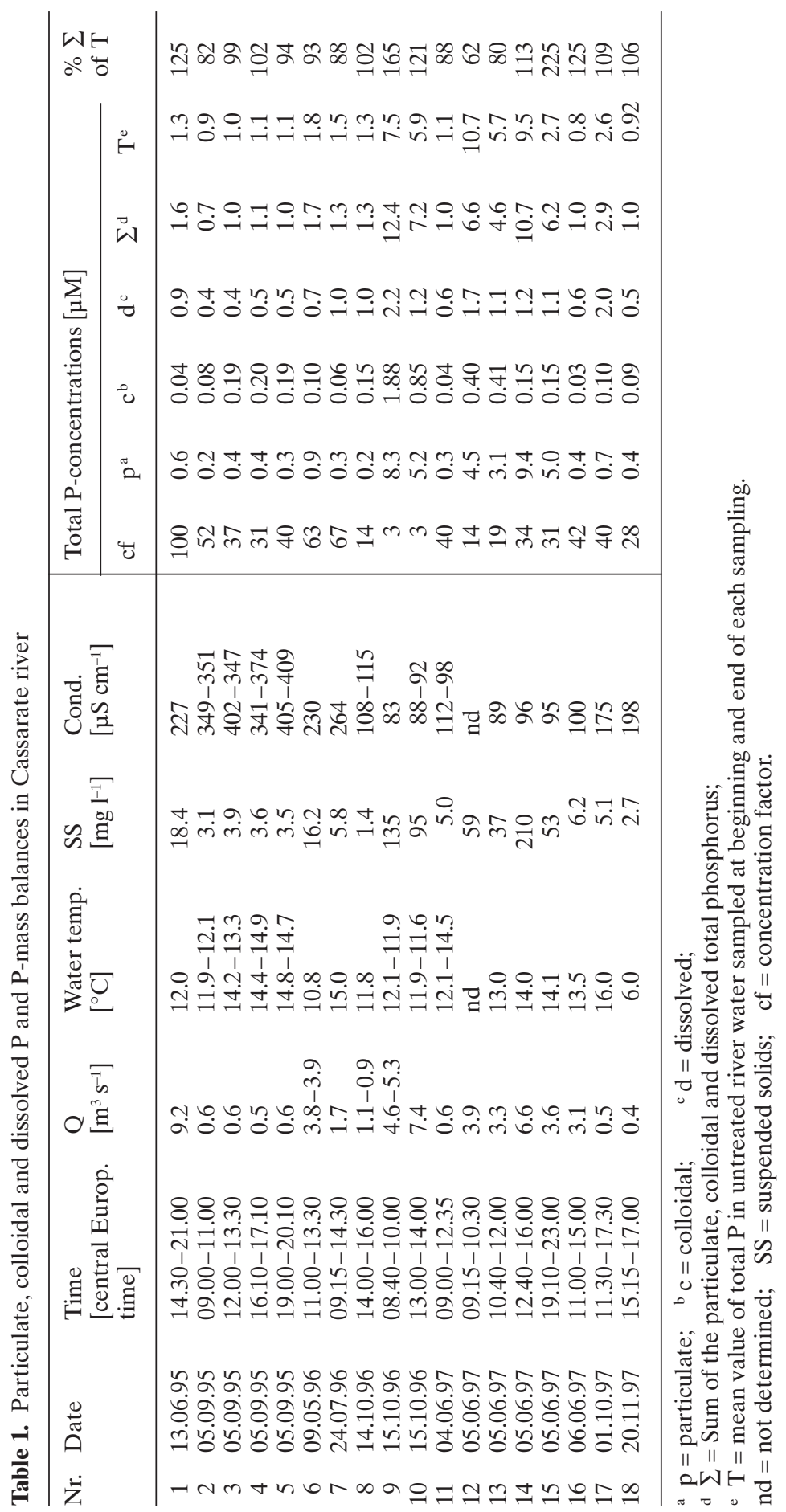




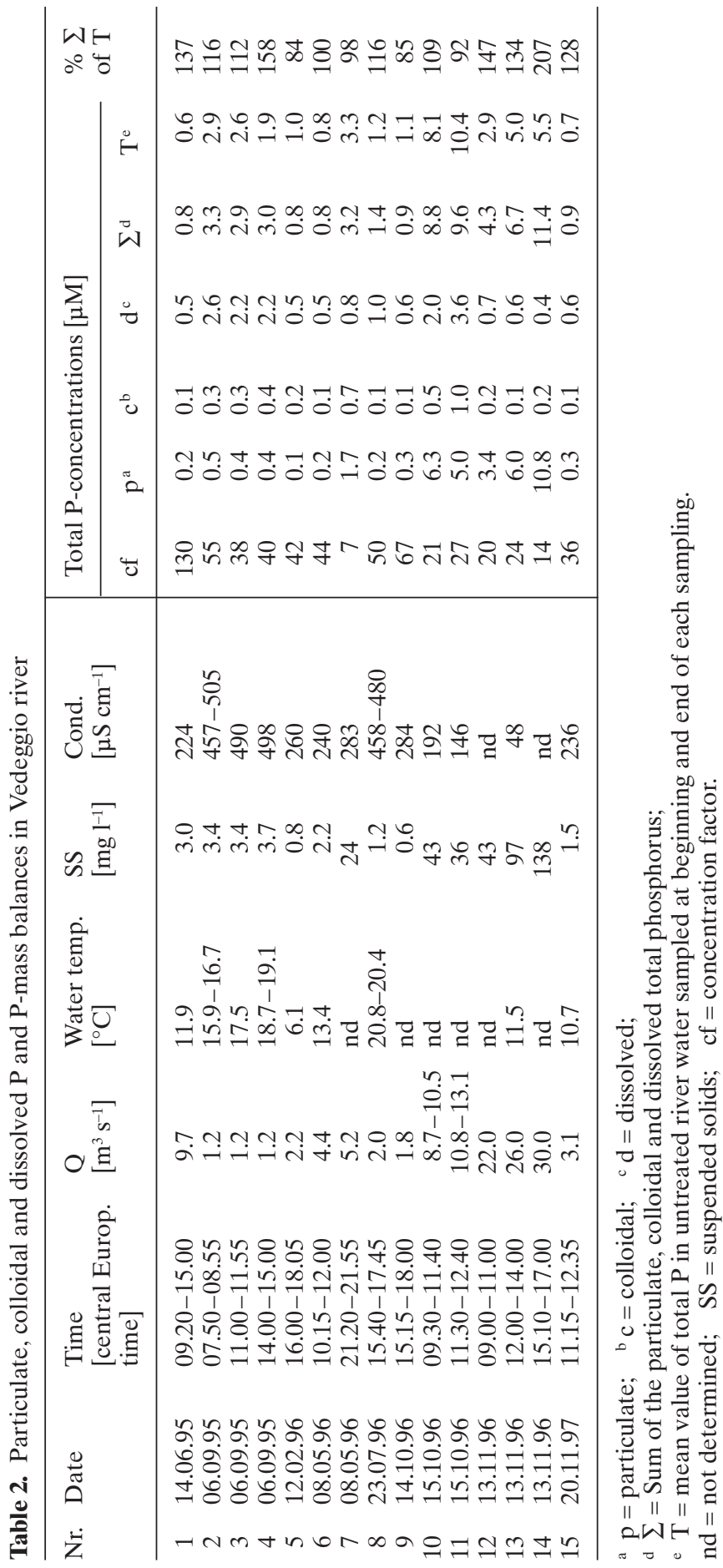


Table 3. Particulate, colloidal and dissolved organic carbon in Cassarate river. Colloidal OC-massbalances refer to untreated water sample and to $0.45 \mu \mathrm{m}$ filtrate

\begin{tabular}{|c|c|c|c|c|c|c|c|c|c|c|}
\hline \multirow[t]{2}{*}{ Nr. } & \multirow[t]{2}{*}{ date } & \multicolumn{7}{|c|}{$\mathrm{TOC}[\mu \mathrm{M}]$} & \multirow{2}{*}{$\begin{array}{l}\%(c+d) \\
\text { of filt. }\end{array}$} & \multirow{2}{*}{$\begin{array}{l}\% \sum \\
\text { of } \mathrm{T}\end{array}$} \\
\hline & & $\mathrm{p}^{\mathrm{a}}$ & $\mathrm{c}^{\mathrm{b}}$ & $\mathrm{d}^{\mathrm{c}}$ & $c+d$ & filt. & $\sum^{\mathrm{d}}$ & $\mathrm{T}^{\mathrm{e}}$ & & \\
\hline 1 & 13.06 .95 & 75 & 6 & 133 & 140 & 136 & 215 & 129 & 103 & 166 \\
\hline 2 & 05.09 .95 & 22 & 13 & 153 & 166 & 134 & 188 & 210 & 124 & 90 \\
\hline 3 & 05.09 .95 & 39 & 33 & 171 & 203 & 203 & 242 & 242 & 100 & 100 \\
\hline 4 & 05.09 .95 & 35 & 20 & 108 & 127 & 110 & 162 & 110 & 115 & 148 \\
\hline 5 & 05.09 .95 & 36 & 17 & 127 & 145 & nd & 180 & 153 & nd & 118 \\
\hline 6 & 09.05 .96 & 69 & 9 & 92 & 101 & 142 & 170 & 133 & 71 & 127 \\
\hline 7 & 24.07 .96 & 41 & 7 & 108 & 111 & 150 & 157 & 150 & 74 & 104 \\
\hline 8 & 14.10 .96 & 11 & 31 & 140 & 171 & nd & 182 & 148 & nd & 123 \\
\hline 9 & 15.10 .96 & 581 & 77 & 141 & 218 & nd & 799 & 622 & nd & 128 \\
\hline 10 & 15.10 .96 & 664 & 157 & 189 & 218 & 210 & 1010 & 808 & 104 & 125 \\
\hline 11 & 04.06 .97 & 23 & 7 & 83 & 90 & nd & 113 & 175 & nd & 65 \\
\hline 15 & 05.06 .97 & 616 & 18 & 150 & 168 & nd & 784 & 462 & nd & 170 \\
\hline 18 & 01.10 .97 & 74 & 13 & 103 & 105 & 108 & 190 & 154 & 97 & 123 \\
\hline 19 & 20.11 .97 & 27 & 15 & 50 & 65 & nd & 93 & 77 & nd & 120 \\
\hline
\end{tabular}

${ }^{\mathrm{a}} \mathrm{p}=$ particulate; ${ }^{\mathrm{b}} \mathrm{c}=$ colloidal; ${ }^{\mathrm{c}} \mathrm{d}=$ dissolved.

d $\sum=$ Sum of the particulate, colloidal and dissolved organic carbon;

e $\mathrm{T}=\mathrm{TOC}$ in untreated water sample.

nd = not determined; filt $=0.45 \mu \mathrm{m}$ filtered.

Table 4. Particulate, colloidal and dissolved organic carbon in Vedeggio river. Colloidal OC-massbalances refer to untreated water sample and to $0.45 \mu \mathrm{m}$ filtrate

\begin{tabular}{|c|c|c|c|c|c|c|c|c|c|c|}
\hline \multirow[t]{2}{*}{$\mathrm{Nr}$} & \multirow{2}{*}{$\begin{array}{l}\text { Sampling } \\
\text { date }\end{array}$} & \multicolumn{7}{|c|}{$\mathrm{TOC}[\mu \mathrm{M}]$} & \multirow{2}{*}{$\begin{array}{l}\%(c+d) \\
\text { of filt. }\end{array}$} & \multirow{2}{*}{$\begin{array}{l}\% \sum \\
\text { of } \mathrm{T}\end{array}$} \\
\hline & & $\mathrm{p}^{\mathrm{a}}$ & $c^{b}$ & $\mathrm{~d}^{\mathrm{c}}$ & $c+d$ & filt. & $\sum^{\mathrm{d}}$ & $\mathrm{T}^{\mathrm{e}}$ & & \\
\hline 1 & $14.06 .95 *$ & 28 & 7 & 178 & 185 & 178 & 213 & 176 & 104 & 121 \\
\hline 2 & 06.09 .95 & 38 & 33 & 198 & 231 & 242 & 270 & 212 & 95 & 127 \\
\hline 3 & 06.09 .95 & 35 & 31 & 242 & 274 & 244 & 308 & 290 & 112 & 106 \\
\hline 4 & 06.09 .95 & 42 & 38 & 197 & 235 & 191 & 278 & 210 & 123 & 132 \\
\hline 6 & 08.05 .96 & 320 & 70 & 125 & 195 & 233 & 515 & 483 & 83 & 107 \\
\hline 8 & 23.07 .96 & nd & 12 & 125 & 137 & 158 & nd & nd & 86 & nd \\
\hline 10 & $15.10 .96 *$ & 637 & 37 & 182 & 220 & nd & 857 & 693 & nd & 124 \\
\hline 11 & $15.10 .96 *$ & 474 & 56 & 157 & 212 & nd & 686 & 728 & nd & 94 \\
\hline 12 & $13.11 .96 *$ & 469 & 43 & 117 & 159 & 142 & 629 & 191 & 113 & 328 \\
\hline 13 & $13.11 .96 *$ & 1140 & 23 & 134 & 157 & 191 & 1297 & 283 & 82 & 458 \\
\hline 14 & $13.11 .96 *$ & 1621 & 61 & 125 & 185 & 183 & 1807 & 283 & 101 & 638 \\
\hline 15 & 20.11 .97 & 12 & 14 & 118 & 132 & nd & 144 & 119 & nd & 122 \\
\hline
\end{tabular}

* = sampling under high discharge.

${ }^{\mathrm{a}} \mathrm{p}=$ particulate; ${ }^{\mathrm{b}} \mathrm{c}=$ colloidal; ${ }^{\mathrm{c}} \mathrm{d}=$ dissolved;

d $\sum=$ Sum of the particulate, colloidal and dissolved organic carbon;

e $\mathrm{T}=$ TOC in untreated water sample.

$\mathrm{nd}=$ not determined; filt $=0.45 \mu \mathrm{m}$ filtered . 


\section{Calculated annual P-loads and depth of intrusion}

The results of the calculated annual P-load with respect to the fractionation for the years 1996 and 1997 are listed in Tables 5 and 6. In general, about $60 \%$ of the annual P-load is particulate, ca. $10 \%$ is colloidal and $30 \%$ is dissolved. The depth of intrusion was calculated as the depth, where the density of the river water is equal to that of the lake water (Wüest, 1996). Temperature and conductivity data profiles from the southern and northern basin of Lake Lugano were taken into account with the water temperature, the conductivity and the suspended solids content and the particle density of the time corresponding river water samples. The calculation showed that the depth of intrusion generally is in the range of the metalimnion to the epilimnion.

\section{$o$-P-release from colloidal $P$}

Release of o-P was observed from both river colloidal suspensions at $\mathrm{pH}$ 10.0-10.2 (Figs. 2 and 3). An increase of the $\mathrm{pH}$ of a colloidal suspension from Cassarate to 8.3 and 9.0 did not show any o-P-release from Cassarate colloids within $15 \mathrm{~min}$. As shown in Figure 2, at a $\mathrm{pH}$ of 10.0-10.2, a significant o-P release takes place within hours. After $24 \mathrm{~h}$, the o-P concentration is about 2.6 times higher compared to the original o-P concentration at a $\mathrm{pH}$ of 7.9. Neither the control of the reagents nor the control of the colloidal suspension at the original $\mathrm{pH}$ showed a significant increase of o-P within $24 \mathrm{~h}$. o-P-concentrations varied within a standard deviation of $\pm 5 \%$. Within $4 \mathrm{~h}$, the same amount of colloidal P, about $4-5 \%$, was released as o-P from both river colloids. Figure 3 shows the increase of o-P concentration in Vedeggio colloids at a $\mathrm{pH}$ of 10.2 .

Table 5. Calculated annual P-load from Cassarate River to Lake Lugano

\begin{tabular}{|c|c|c|c|c|}
\hline Low discharge & \multicolumn{2}{|c|}{$\begin{array}{l}\text { Average } \\
\text { P-distribution \% }\end{array}$} & $\begin{array}{l}1996 \mathrm{P} \text {-input } \\
{\left[\mathrm{t} \mathrm{P} \mathrm{a}^{-1}\right]}\end{array}$ & $\begin{array}{l}1997 \mathrm{P} \text {-input } \\
{\left[\mathrm{t} \mathrm{P} \mathrm{a}^{-1}\right]}\end{array}$ \\
\hline dissolved & \multicolumn{2}{|l|}{59} & 1.6 & 0.7 \\
\hline colloidal & \multicolumn{2}{|l|}{10} & 0.3 & 0.1 \\
\hline particulate & \multicolumn{2}{|l|}{31} & 0.9 & 0.3 \\
\hline \multicolumn{5}{|l|}{ High discharge } \\
\hline dissolved & \multicolumn{2}{|l|}{17} & 0.8 & 1.0 \\
\hline colloidal & \multicolumn{2}{|l|}{10} & 0.5 & 0.6 \\
\hline particulate & \multicolumn{2}{|l|}{73} & 3.5 & 4.3 \\
\hline Annual average & 1996 & 1997 & 1996 & 1997 \\
\hline dissolved & 32 & 24 & 2.4 & 1.7 \\
\hline colloidal & 10 & 10 & 0.75 & 0.7 \\
\hline particulate & 58 & 66 & 4.35 & 4.6 \\
\hline \multicolumn{3}{|l|}{ total annual $\mathrm{P}$-load $\left[\mathrm{t} \mathrm{P} \mathrm{a}^{-1}\right]$} & 7.5 & 7.0 \\
\hline
\end{tabular}


Table 6. Calculated annual P-load from Vedeggio River to Lake Lugano

\begin{tabular}{llll}
\hline Low discharge & $\begin{array}{l}\text { Average } \\
\text { P-distribution \% }\end{array}$ & $\begin{array}{l}1996 \mathrm{P} \text {-input } \\
{\left[\mathrm{t} \mathrm{P} \mathrm{a}^{-1}\right]}\end{array}$ & $\begin{array}{l}1997 \mathrm{P} \text {-input } \\
{\left[\mathrm{f} \mathrm{a} \mathrm{a}^{-1}\right]}\end{array}$ \\
\hline dissolved & 68 & 1.0 & 1.2 \\
colloidal & 12 & 0.2 & 0.3 \\
particulate & 19 & 0.3 & 0.3 \\
\hline
\end{tabular}

High discharge

\begin{tabular}{lrrll}
\hline dissolved & 19 & & 0.7 & 1.3 \\
colloidal & 8 & & 0.3 & 0.5 \\
particulate & 73 & & 2.8 & 4.8 \\
\hline Annual average & 1996 & 1997 & 1996 & 1997 \\
\hline dissolved & 30 & 30 & 1.6 & 2.5 \\
colloidal & 8 & 9 & 0.4 & 0.8 \\
particulate & 62 & 61 & 3.3 & 5.1 \\
\hline total annual P-load $\left[\mathrm{t} \mathrm{P} \mathrm{a}^{-1}\right]$ & & & 5.3 & 8.4 \\
\hline
\end{tabular}

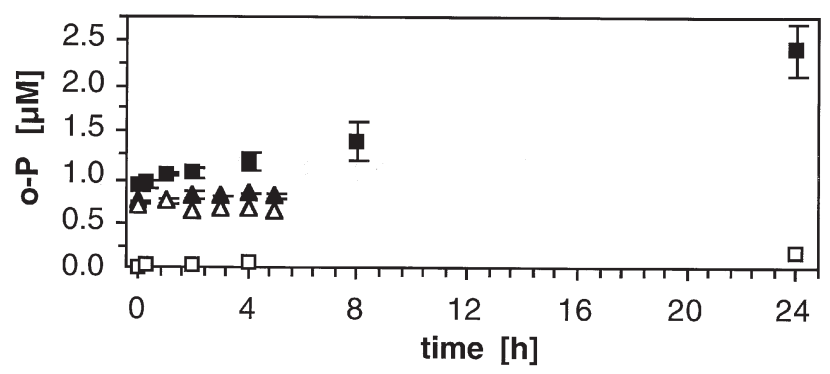

Figure 2. o-P-release at a $\mathrm{pH}$ of 10 (filled squares) and 10.2 (filled triangles) from Cassarate colloids. Means and standard deviation of the o-P-concentrations in $0.2 \mu \mathrm{m}$ filtered samples are shown $(\mathrm{n}=3)$ at $20^{\circ} \mathrm{C}$. Control at $\mathrm{pH} 10$ is the o-P-concentration in demineralized water at $\mathrm{pH} 10$ and under nitrogen gas atmosphere (open squares). The o-P-concentration in $0.2 \mu \mathrm{m}$-filtered colloidal retentate at the original $\mathrm{pH}$ of 7.9 is also shown (open triangles)

Release of o-P from both river colloids in the presence of alkaline phosphatase is shown in Figures $4 \mathrm{a}$ and $\mathrm{b}$. The results with low enzyme concentrations of 3 and $20 \mathrm{u} \mathrm{l}^{-1}$ did not show a clear trend in the o-P release. This might be due to enzyme flocculation or an enzyme inhibition through o-P (Olsson, 1988). However, with higher enzyme concentrations of 114 and $230 \mathrm{u} \mathrm{l}^{-1}$ the o-P concentration in the ultrafiltrate nearly doubled after $1 \mathrm{~h}$. At the most $17-19 \%$ of the colloidal $\mathrm{P}$ was released as o-P with $230 \mathrm{u} \mathrm{l}^{-1}$ enzyme concentration from both river colloids. The control showed a constant o-P concentration within $5 \mathrm{~h}$ with a standard deviation of $\pm 2.7 \%(\mathrm{n}=2)$. Measurements of the enzyme activity in the colloidal suspension 


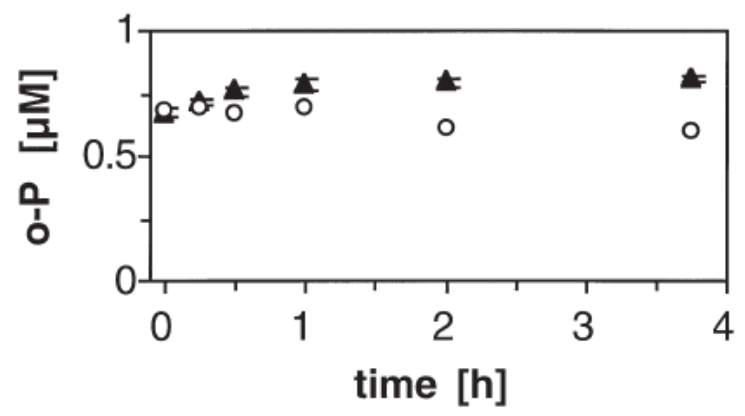

Figure 3. o-P-release at a $\mathrm{pH}$ of 10.2 from Vedeggio colloids. Means and standard deviation of the o-P-concentrations in $0.2 \mu \mathrm{m}$ filtered samples are shown $(\mathrm{n}=3)$ at $20^{\circ} \mathrm{C}$ (filled triangles). Control shows the o-P-concentration in $0.2 \mu \mathrm{m}$-filtered colloidal retentate at the original $\mathrm{pH}$ of 7.9 (open circles)

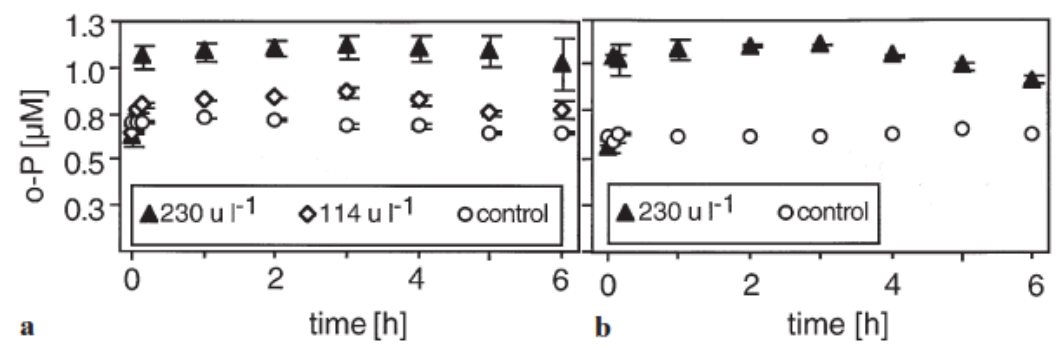

Figure 4. Enzymatic o-P release from colloids with alkaline phosphatase. Means and standard deviations are shown $(n=2)$. Controls shown are o-P-concentration in the ultrafiltrate from Cassarate and Vedeggio colloids without alkaline phosphatase. a o-P concentration in the ultrafiltrate from Cassarate colloids ( 3 days after sampling) at $30^{\circ} \mathrm{C}$, with 114 or $230 \mathrm{u} \mathrm{l}^{-1}$ alkaline phosphatase added. b o-P concentration in the ultrafiltrate from Vedeggio colloids ( 1 and 2 days after sampling) at $30^{\circ} \mathrm{C}$, with $230 \mathrm{u} \mathrm{l}^{-1}$ alkaline phosphatase added

showed an activity of only $4 \%$ of the enzyme specific activity value in the experiments with low enzyme concentrations. In the experiments with $114 \mathrm{u} \mathrm{l}^{-1}$, the activity was $26 \pm 4 \%$ and in the experiments with $230 \mathrm{u} \mathrm{l}^{-1}$, the enzyme activity comprised $52 \pm 10 \%$.

\section{Discussion}

\section{In-situ fractionation}

A similar dependence of the P-concentrations and $\mathrm{P}$ size distributions on discharge was observed in both rivers. No seasonal effects were observed. The distribution of dissolved and particulate $\mathrm{P}$ is strongly influenced by the discharge. Under high discharge, the particulate fraction is dominant, whereas under low discharge the dissolved fraction is the dominating one. 
The mass balance approach showed good results with a mean of $100 \%$ and a standard deviation of $14-20 \%$. Only few examples showed a larger difference, which can be explained with the uncertainity of the analysis of the reference samples taken at the beginning and the end of each sampling. Variations in the suspended solid content strongly influence the mass balance and also the total P-content in the unfractionated reference sample. Bauer et al. (1996) showed that the P-concentration in the ultrafiltrate did not vary over filtration time. We also assumed that the P-concentration in the ultrafiltrate stays constant over the filtration time.

An important question is the source of colloidal and particulate $\mathrm{P}$, as both concentrations increase with raising discharge. Due to the morphology of both catchment areas, soil erosion is one important diffuse source for the increasing particle and colloid input under storm events. Resuspension of river sediment is another important source for particles and colloids. After longer dry periods, the wash out from sewers lead to an high P-input, which mostly consists of colloids and particles. Another P-source is the sewage treatment plant in Bioggio where incompletely treated waste water, bulking sludge and scumming sludge entered the Vedeggio river during heavy rain fall events lasting more than 2 days.

Interestingly, the colloidal P-fraction shows an average amount of $10 \%$ of total $\mathrm{P}$ independently of discharge, while the dissolved fraction is dominating under low discharge and the particulate one dominates under high discharge conditions. This leads to the conclusion that colloidal P-pools from either point or diffuse sources must become active with rain and increasing discharge, because the colloidal P-concentration increases under high discharge. However, with an increasing number of colloids per volume, aggregation is strongly enhanced, which would lead to a relative loss of colloidal P. On the other hand, the conductivity diminishes by about 2-8 times. Therefore, the lower ionic strength increases the colloidal stability.

Our results can be compared with only few other studies about colloidal $\mathrm{P}$ in aquatic systems. Bauer et al. (1996) defined the colloidal fraction in the size range of $<0.2 \mu \mathrm{m}$ membrane filtered and $>1 \mathrm{kD}$ cross-flow-filtered. The colloidal P-fraction of different seawater samples made 1 to $20 \%$ of the total P (1-3 $\mu \mathrm{M} \mathrm{P})$, which is in agreement with the results of this work. A wider range for the colloidal $\mathrm{P}$ fraction of $0-48 \%$ in creek water samples was reported by Mayer and Jarrell (1995). They define the colloidal fraction as the difference between $1.0-\mu \mathrm{m}-$ and $0.05-\mu \mathrm{m}-$ membrane filtered samples.

\section{C-fractionations and mass-balances}

The OC-distribution of the different fractions are in agreement with those of the P-distribution. The particulate and dissolved, ultrafiltered OC are also strongly dependent from discharge. The results of the COC-fractions (comprising 1-17\% of TOC) are in good agreement with the results of Rostad et al. (1997), who found between 1.1-17\% of COC in the Mississippi River and its tributaries. Buesseler et al. (1996) showed with an intercomparison study that there are huge differences of $4-67 \%$ of COC between various manufacturers of cross-flow filtration systems. However, good results for OC with a reproducibility of $91-106 \%$ using a cross-flow filtration with a $10 \mathrm{kD}$ cut-off and $1 \mathrm{kD}$ with different seawater samples and total 
DOC and COC-concentrations of $50-250 \mu \mathrm{M} C$ were observed by Whitehouse et al. (1990) and Guo and Santschi (1996). In a colloidal size range between $0.4 \mu \mathrm{m}$ and $10 \mathrm{kD} 82-98 \%$ of the $0.4 \mu \mathrm{m}$ DOC were in the colloidal fraction in samples of the Venice Lagoon (Martin et al., 1995). Most workers do not take into account the particulate organic fraction in the mass balance approach, but only compare the sum of colloidal OC and ultrafiltered DOC with a reference sample, which has been membrane filtered (mostly $0.45 \mu \mathrm{m}$ ). Our comparison of the sum of COC and ultrafiltered DOC also shows reasonable agreement with a $0.45-\mu \mathrm{m}$ filtered water sample with a standard deviation of $25 \%$, which is comparable to the cited authors.

\section{Availability of colloidal P in Lake Lugano}

Calculation of the size distribution of the average annual P-loads showed that approximately $60 \%$ of the total P-input is particulate, $10 \%$ colloidal and $30 \%$ dissolved. Most of the dissolved $\mathrm{P}$ is o-P which is directly usable for bacteria and algae growth (Boström et al., 1988). As colloids have a lower density and a smaller diameter than particles, their residence times in the epilimnion or in the water column may be quite long. As the calculated depth of intrusion lays within the productive zone, colloids can be considered as a potentially available P-pool. A significant amount of o-P release from river colloids could be observed at increased $\mathrm{pH}$ of 10.0-10.2 within few hours, and also in the presence of alkaline phosphatase, which is excreted by algae and bacteria (Francko and Heath, 1979; Olsson, 1988; Yiyong, 1996). $\mathrm{pH}$ in the epilimnion of Lake Lugano reaches values between 8.7 (June/July) and 9.4 (August), whereas the $\mathrm{pH}$ of both rivers are between 7.0 and 7.9 (LSA, 1996). Therefore the hydrolysis of organic phosphorus-esters could be a mechanism for the o-P-supply under o-P-deficiency, especially when o-P is depleted from the euphotic layers in summer. The availability of $\mathrm{P}$ from the particulate fraction is less likely to play a relevant role, since the particles are quickly transported to the deeper water layers. In contrast, the colloidal P-fraction with a longer residence time in the euphotic layers may contribute to the available P.

\section{ACKNOWLEDGEMENTS}

We thank David Kistler, Daniel Kobler, René Schönenberger, Adrian Amman, Hans-Ruedi Zweifel for field work. Thomas Rüttimann and Antonin Mares are acknowledged for the TOC- and POC-analyses. We also thank Christoph Mattenberger for calculation support. The authorities of Cantone Ticino are acknowledged for data exchange and field support. This work was supported by the Swiss National Science Foundation, within the SPPU program.

\section{REFERENCES}

APHA, AWWA and WEF, 1995. Standard Methods for the Examination of Water and Wastewater. American Public Health Association, Washington.

Baccini, P., 1985. Einschränkung des Phosphatverbrauches - Ein Beitrag zum Gewässerschutz. GWA, 1: 1-6.

Barbieri, A. and R. Mosello, 1992. Chemistry and trophic evolution of Lake Lugano in relation to nutrient budget. Aquat. sci. 54(3-4): 219-237. 
Bauer, J.E., K.C. Ruttenberg, D.M. Wolgast, E. Monaghan and M.K. Schrope, 1996. Cross flow filtration of dissolved and colloidal nitrogen and phosphorus in seawater: results from an intercomparison study. Mar. Chem. 55(1-2): 33-52.

Boström, B., G. Persson and B. Broberg, 1988. Bioavailability of different phosphorus forms in freshwater systems. Hydrobiologia 170: 133-155.

Bretaudiere, J.P. and T. Spillman, 1984. Methods of Enzymatic Analysis - Enzymes 2: Esterases, Glycosidases, Lyases, Ligases, IV. Verlag Chemie, Weinheim, Basel.

Buesseler, K.O., J.E. Bauer, R.F. Chen, T.I. Eglinton, O. Gustafsson, W. Landing, K. Mopper, S.B. Moran, P.H. Santschi, R. Vernonclark and M.L. Wells, 1996. An intercomparison of cross flow filtration techniques used for sampling marine colloids: overview and organic carbon results. Mar. Chem. 55(1-2): 1-31.

Buffle, J. and G.G. Leppard, 1995. Characterization of Aquatic Colloids and Macromolecules. 1. Structure and Behaviour of Colloidal Material. Environ. Sci. Technol. 29(9): 2169-2175.

Buffle, J. and H.P. van Leeuwen, 1992. Environmental particles. Environmental analytical and physical chemistry series. Lewis Publishers, Boca Raton/FL, USA.

BUWAL, 1994. Der Zustand der Schweizer Seen, Bern.

Everett, D.H., 1988. Basic principles of colloid chemistry. Royal Society of Chemistry, London.

Eyrolle, F., M.F. Benedetti, J.Y. Benaim and D. Fevrier, 1996. The distribution of colloidal and dissolved organic carbon, major elements, and trace elements in small tropical catchments. Geochim. Cosmochim. Acta 60(19): 3643-3656.

Francko, D.A. and R.T. Heath, 1979. Functionally distinct classes of complex phosphorus compounds in lake water. Limnol. Oceanogr. 24(3): 463- 473.

Gächter, R. and P. Stadelmann, 1993. Gewässerschutz und Seenforschung. In: E. Rouss (ed.), Der Sempachersee. Mitt. Naturforsch. Ges. Luzern, pp. 343.

Gächter, R. and A. Wüest, 1992. Auswirkungen von Sanierungsmassnahmen auf den Trophiegrad und Sauerstoffhaushalt von Seen. EAWAG News, 34D: 27-32.

Guo, L.D. and P.H. Santschi, 1996. A critical evaluation of the cross flow ultrafiltration technique for sampling colloidal organic carbon in seawater. Mar. Chem. 55(1-2): 113-127.

Gustafsson, Ö. and P.M. Gschwend, 1997. Aquatic colloids: Concepts, definitions, and current challenges. Limnol. Oceanogr. 42 (3): 519-528.

Hilger, S., 1998. Characterization of colloidal and particulate phosphorus in two Lake Lugano tributaries. Ph. D. Thesis, ETH, Zürich, 140 pp.

Hoffmann, M.R., E.C. Yost, S.J. Eisenreich and W.J. Maier, 1981. Characterization of Soluble and Colloidal-Phase Metal Complexes in River Water by Ultrafiltration. A Mass-Balance Approach. Environ. Sci. Techn. 15(6): 655-661.

Imboden, D., 1992. Possibilities and limitations of lake restoration: Conclusions for Lake Lugano. Aquat. sci. 54(3-4): 381-390.

Jackson, T.A. and D.W. Schindler, 1975. The biogeochemistry of phosphorus in an experimental lake environment: evidence for the formation of humic-metal-phosphate complexes. Verh. int. Ver. Limnol. 19: 211-221.

Karagounis, I., 1992. Ein physikalisch-biochemisches Seemodell - Anwendung auf das Nordbecken des Luganer Sees. VAW Mitteilungen, 116. Versuchsanstalt für Wasserbau, Hydrologie und Glaziologie der ETH Zürich, Zürich, 1-156 pp.

Lachavanne, J.B., J. Perfetta and R. Juge, 1992. Influence of water eutrophication on the macrophytic vegetation of Lake Lugano. Aquat. sci. 54(3-4): 351-363.

Lami, A., P. Guilizzoni, D. Ruggiu, B. Polli, M. Simona and A. Barbieri, 1992. Role of pigments on algal communities and photosynthesis. Aquat. sci. 54(3-4): 321-330.

Lazzaretti, M.A., K.W. Hanselmann, H. Brandl, D. Span and R. Bachofen, 1992. The role of sediments in the phosphorus cycle in Lake Lugano: II. Seasonal and spatial variability of microbiological processes at the sediment-water interface. Aquat. sci. 54 (3-4): 285-299.

Lead, J.R., W. Davison, J. Hamilton-Taylor and J. Buffle, 1997. Characterizing Colloidal Material in Natural Waters. Aquatic Geochemistry, 3: 213- 232.

Lean, D.R.S., 1973. Phosphorus dynamics in lakewater. Science, 179: 768-680.

LSA, 1996. „Ricerche sull evoluzione del Lago di Lugano“-Aspetti limnologici. Programma quinquennale 1993-1997 (campagna 1993). ISSN 1013-8080, Laboratorio Studi Ambientali (LSA). Commissione Internazionale per la protezione delle Acque Italo-Svizzere, Cantone Ticino. 
LSA, 1998. "Ricerche sull evoluzione del Lago di Lugano"-Aspetti limnologici. Programma quinquennale 1993-1997 (campagna 1996 e 1997), Laboratorio Studi Ambientali (LSA). Commissione Internazionale per la protezione delle Acque Italo-Svizzere, Cantone Ticino.

Martin, J.M., M.H. Dai and G. Cauwet, 1995. Significance of colloids in the biogeochemical cycling of organic carbon and trace metals in the Venice Lagoon (Italy). Limnol. Oceanogr. 40(1): $119-131$.

Mayer, T.D. and W.M. Jarrell, 1995. Assessing Colloidal Forms of Phosphorus and Iron in the Tualatin River Basin. J. Environ. Qual. 24: 1117-1124.

Müller, R. and H.J. Meng, 1992. Past and present state of the ichthyofauna of Lake Lugano. Aquat. sci. 54(3-4): 338-350.

Olsson, H., 1988. Phosphatases in Lakes- Characterization, Activity and Ecological Implications, Uppsala University, Uppsala.

Paerl, H.W. and D.R.S. Lean, 1976. Visual Observations of Phosphorus Movement between algae, bacteria and abiotic particles in Lake Waters. J. Fish. Res. Board Can. 33: 2805-2813.

Polli, B. and M. Simona, 1992. Qualitative and quantitative aspects of the evolution of the planktonic populations in Lake Lugano. Aquat. sci. 54(3-4): 303-320.

Rigler, F.H., 1964. The phosphorus fractions and the turnover time of inorganic phosphorus in different types of lakes. Limnol. Oceanogr. 9: 511-518.

Rostad, C.E., J.A. Leenheer and S.R. Daniel, 1997. Organic Carbon and Nitrogen Content Associated with Colloids and Suspended Particulates from the Mississippi River and Some of Its Tributaries. Environ. Sci. Technol. 31: 3218-3225.

Schurtenberger, P. and M.E. Newman, 1993. Characterization of Biological and Environmental Particles using Static and Dynamic Light Scattering. In: J. Buffle and H.P.v. Leeuwen (eds.), Environmental Particles. Environmental Analytical and Physical Chemistry Series. Lewis Publishers, Boca Raton/FL, USA.

Siegrist, H. and M. Boller, 1996. Auswirkungen des Phosphatverbots auf die Abwasserreinigung, EAWAG News, 42 D: 9-11.

Vollenweider, R.A., 1968. Scientific fundamentals of the eutrophication of lakes and flowing waters, with particular reference to nitrogen and phosphorus as factors in eutrophication, 27, OECD, Paris, 159 pp.

Wehrli, B. and A. Wüest, 1996. 10 Jahre Seenbelüftung: Erfahrungen und Optionen. Schriftenreihe der EAWAG, Nr. 9., EAWAG, Dübendorf.

Whitehouse, B.G., P.A. Yeats and P.M. Strain, 1990. Cross-flow filtration of colloids from aquatic environments. Limnol. Oceanogr. 35(6): 1368-1375.

Wüest, A., 1996. Einschichtungen partikelbeladener Zuflüsse in Seen, Peak-Kurs, EAWAG, Duebendorf.

Yiyong, Z., 1996. UV-sensitive P compounds: release mechanism, seasonal fluctuation and inhibitory effects on alkaline phosphatase activity in a shallow Chinese freswater lake (Donghu Lake). Hydrobiologia, 335: 55- 62.

Zamboni, F., A. Barbieri, B. Polli, G. Salvade and M. Simona, 1992. The dynamic model Seemod applied to the southern basin of Lake Lugano. Aquat. sci. 54(3-4): 367-380.

Received 19 October 1998;

revised manuscript accepted 6 May 1999. 